\title{
原著論文
}

\section{ICU における慢性呼吸不全の急性増悪の管理}

\author{
西田 修*1 高須宏江*2 伊藤彰師*2 \\ 栗山康介*2 八田 誠*1 石川 清*1
}

\begin{abstract}
要旨 慢性呼吸不全症例では, 非可逆的な病変の進行, 残存呼吸予備能の低下等により, 急性増悪時 の管理はむずかしい.ICUに収容した，185名の慢性呼吸不全患者の急性増悪の管理について retrospective に調査した。その結果，これらの患者では，入退室を繰り返す，在室日数が長い，原疾患 として肺結核が多い，という特徵がみられた。急性増悪は冬と夏に多く，死亡率は春と秋の入室者 に高いという，季節との関係がみられた。また，入室時に意識障害の認められた症例では死亡率が 高かった．全体の死亡率は $10.8 \%$ であり，ミ二気管切開（トラヘルパー®）の導入により若干の死 亡率の低下と在室日数の大幅な減少が得られた。
\end{abstract}

\section{I はじめに}

慢性呼吸不全患者の急性増覀時の管理につい ては, 従来より微量酸素投与, 呼吸促進剤投与, 気管内捚管による人工呼吸管理などが行なわれ ているが，長期にわたる根気強い管理を余儀な くされることも多い，急性呼吸不全と異なり， 慢性呼吸不全症例では, 非可逆的な病変が進行 しており，残された呼吸予備能はわずかな場合 が多い。そのため，安定期においても微妙なバ ランスの上に立っており，わずかな誘因でも， 急性増悪のトリガーとなりうる。一旦増悪す ると，許容範囲が狭いため管理が非常に困難で あり，一時的に改善したとしても反復して進行
悪化する場合が多い。これらの患者の急性増悪 時には, 各種臟器の障害1)や，循環変動 2 などを 伴うことも多く，呼吸管理のみならず全身管理 を必要とし,しばしば ICU 管理の対象となる。 今回，我々は，名古屋第二赤十字病院集中治療 部（以下 ICU）に収容した慢性呼吸不全患者の 急性増悪時について検討したので報告する。

\section{II 対 象}

1980 年 1 月 1 日から 1988 年12月 31 日の 9 年間 に, 当院の呼吸器内科病棟入院中および当院救 急外来を受診した慢性呼吸不全患者で, 急性増 悪をきたし ICU 管理を必要とした患者延べ185 名を対象とした。

*1名古屋市立大学医学部麻酔・蘇生学教室

*2名古屋第二赤十字病院集中治療部受理日 1990.5 .22 
表 1 対象患者の年度別概要

\begin{tabular}{|c|c|c|c|c|c|c|c|c|c|c|}
\hline & 80 年 & 81 年 & 82 年 & 83年 & 84年 & 85 年 & 86 年 & 87 年 & 88年 & st \\
\hline 人室者数（人） & 11 & 14 & 14 & 14 & 20 & 34 & 35 & 23 & 20 & 185 \\
\hline 年 & $\begin{array}{r}55.9 \\
\pm 12.7 \\
\end{array}$ & $\begin{array}{l}55.0 \\
\pm 15.4\end{array}$ & $\begin{array}{l}43.6 \\
\pm 12.1 \\
\end{array}$ & $\begin{array}{r}62.8 \\
\pm 9.0 \\
\end{array}$ & $\begin{array}{l}70.9 \\
\pm 9.0\end{array}$ & $\begin{array}{r}61.1 \\
\pm 14.0\end{array}$ & $\begin{array}{l}59.6 \\
\pm 16.1 \\
\end{array}$ & $\begin{array}{c}65.5 \\
\pm 12.9 \\
\end{array}$ & $\begin{array}{c}73.1 \\
\pm 6.1 \\
\end{array}$ & $\begin{array}{c}61.8 \\
\pm 14.6 \\
\end{array}$ \\
\hline 男：女 （人） & $8: 3$ & $7: 7$ & $6: 8$ & $12: 2$ & $16: 4$ & $27: 7$ & $23: 12$ & $21: 2$ & $16: 4$ & $136: 49$ \\
\hline 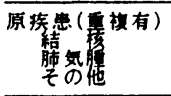 & $\begin{array}{l}8 \\
4 \\
3\end{array}$ & $\begin{array}{r}10 \\
8 \\
1\end{array}$ & $\begin{array}{r}13 \\
1 \\
0\end{array}$ & $\begin{array}{r}11 \\
2 \\
2\end{array}$ & $\begin{array}{r}16 \\
3 \\
4\end{array}$ & $\begin{array}{r}21 \\
9 \\
23\end{array}$ & $\begin{array}{r}15 \\
8 \\
29 \\
\end{array}$ & $\begin{array}{r}13 \\
5 \\
12 \\
\end{array}$ & $\begin{array}{r}10 \\
6 \\
3\end{array}$ & $\begin{array}{r}117 \\
46 \\
77\end{array}$ \\
\hline $\begin{array}{l}\text { 在室日 数 (旦) } \\
\text { (mean } \pm \text { SE) }\end{array}$ & $\begin{array}{l}8.3 \\
\pm 1.6 \\
\end{array}$ & $\begin{array}{l}11.1 \\
\pm 2.6 \\
\end{array}$ & $\begin{array}{c}13.8 \\
\pm 3.6\end{array}$ & $\begin{array}{r}27.9 \\
\pm 6.4 \\
\end{array}$ & $\begin{array}{c}11.4 \\
\pm 2.5 \\
\end{array}$ & $\begin{array}{l}11.6 \\
\pm 1.9\end{array}$ & $\begin{array}{r}12.8 \\
\pm 2.9 \\
\end{array}$ & $\begin{array}{l}8.7 \\
\pm 1.7 \\
\end{array}$ & $\begin{array}{l}5.7 \\
\pm 0.9\end{array}$ & $\begin{array}{r}16.7 \\
\pm 4.0\end{array}$ \\
\hline 死 ᄃ & $0 / 11$ & $2 / 14$ & $1 / 14$ & $2 / 14$ & $5 / 20$ & $1 / 34$ & $3 / 35$ & $2 / 23$ & $4 / 20$ & $20 / 185$ \\
\hline
\end{tabular}

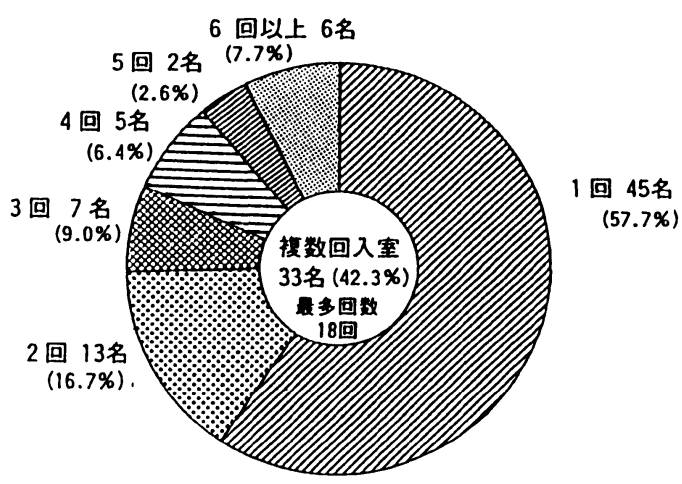

図 1 ICU 入室回数

\section{III 方 法}

上記対象患者について, retrospective に調査 し, 患者背景, ICU 在室日数, 入室者数の推移, 予後に影響を与える因子を調べた。また，呼吸 刺激薬 (Doxapram), ミニ気管切開 (トラヘル パー®）の有用性についても検討を加えた。統 計処理は, Student's t-test， $\chi^{2}$ 検定を用い， $\mathrm{p}<0.05$ で有意差ありとした。

\section{IV 結 果}

対象患者の概要を年度別に表 1 に示した。

ICU 入室者数推移は, 85 年と 86 年をピークに 近年減少の傾向がみられた。

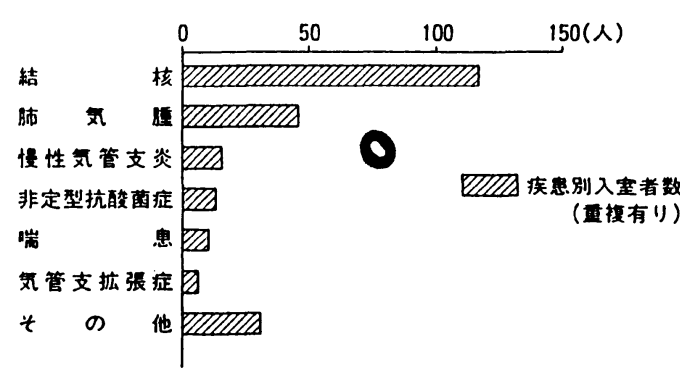

図 2 原疾患別入室者数

対象となった185名は，この間の ICU 全入室 患者3,048名の約 $6 \%$ に相当した.このうち 33 名 は複数回入室者であり，実数は78名であった。

入退室を繰り返す患者が多く, 複数回入室し た患者は $42.3 \%$ にあたり，4 人に 1 人は 3 回以 上，最多入室回数は 18 回であった（図 1 ).

185名の平均年齢は, $61.8 \pm 14.6$ 歳 (34〜95歳) であり,男女比は男 $73.5 \%$ ：女 $26.5 \%$ あっった。

救命率は $89.2 \%$ にのほり，この間の ICU 全体 の救命率 $80.3 \%$ を回っていた.

原疾患の疾患別入室者数の割合では, 胸廓形 成術後などの結核後遺症患者が117名（63.2\%） であり，続いて肺気腫46名（24.2\%）であった (図 2 )。なお，原疾患による死亡率に有意差は 認められなかった。 また, 近年は, 結核後遺症 以外の割合が増加している（図 3 ）。 


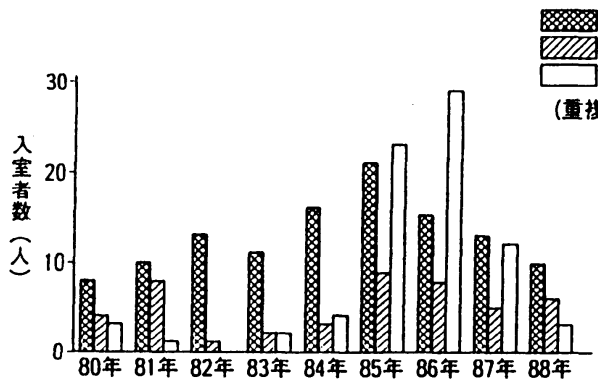

図 3 原疾患別入室者数の推移

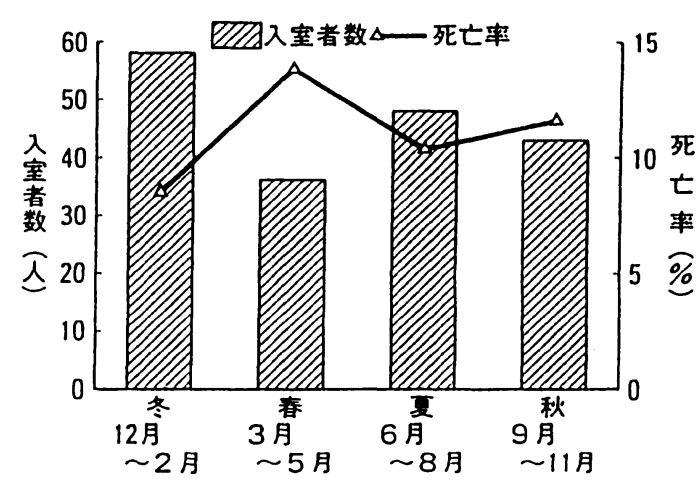

図4 季節別動向
病棟および救急外来からの入室の割合は, そ

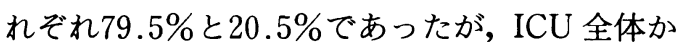
らみた病棟からの入室者数の割合 $39.2 \%$ に比 し, 病棟からの入室が有意に多かった（ $\mathrm{p}<$ 0.01). なお, 病棟からの入室群と救急外来から の入室群の間に死亡率の差は認められなかっ た.

季節別入室者数と死亡率をみると, 入室者数 は冬と夏に多く, 春に少ない傾向にあり, 冬と 春の間には有意差が認められた $(\mathrm{p}<0.05)$. し かし, 死亡率は入室者数とは全く反対の傾向が みられ，冬と夏に低く春に高かった（図 4 ）。

$70.3 \%$ に室時意識障害 $(3-3-9$ 度で 2 以 上)が認められた。意識障害の認められた群と, 認められなかった群で死亡率を比較すると, そ れぞれ $13.8 \%, 3.6 \%$ あり, 意識障害の認めら れた群では有意に死亡率が高かった（p< $0.05)$.

入室時の $\mathrm{PaCO}_{2}$ は $84.2 \pm 19.7 \mathrm{~mm} \mathrm{Hg}$ (43〜 180mm Hg)であり, 生存群, 死亡群ではそ れぞれ $84.6 \mathrm{~mm} \mathrm{Hg} \pm 20.24 \mathrm{~mm} \mathrm{Hg}, 80.6 \pm 14.78 \mathrm{~mm}$ $\mathrm{Hg}$ であり, 死亡群の方が低い傾向を示したが 有意差は認められなかった。

呼吸刺激薬Doxapram の投与は59名
(32.1\%) に行ない,そのうち12名 $(23.1 \%)$ に ついては, 気管内挿管を回避し得た。Doxapram 投与群と非投与群の死亡率は, それぞれ $13.6 \%$, $8.2 \%$ あり,有意差は認められなかったものの Doxapram 投与群の方が高かった。

延べ入室185名中, 入室時すでに気管切開を施 行されていた症例は39名であり，これを除いた 146例のうち，117例（80.1\%）は気管内挿管を 必要とした。さらに，これらの挿管患者の18例 （15.4\%）に，気管切開を施行した.

平均在室日数は全体でみると，16.7 44.0 日 (Mean士SE) で最長は702日であった。一方, 気 切群 (気管切開済の患者を除く) では $33.8 \pm 5.7$ 日と有意に長かった $(\mathrm{p}<0.05)$. また, 気管切 開施行に至るまでの挿管回数は2.7 1.97 回で あり, 挿管群（非気切群）の挿管回数 $1.4 \pm 0.9$ 回に比し有意に多かった $(\mathrm{p}<0.01)$. トラヘル パー ${ }^{\circledR}$ 挿入例の入室者数に占める割合の年度別 推移では，85年トラヘルパー®の導入以降これ が著増し，88年には $40 \%$ に達した。一方で，気 切施行例の割合は 83 年の $28.6 \%$ をピークに激減 し，88年には $5 \%$ にとどまった。また，トラへ ルパー® 導入前後の在室日数, 死亡率を比較す 

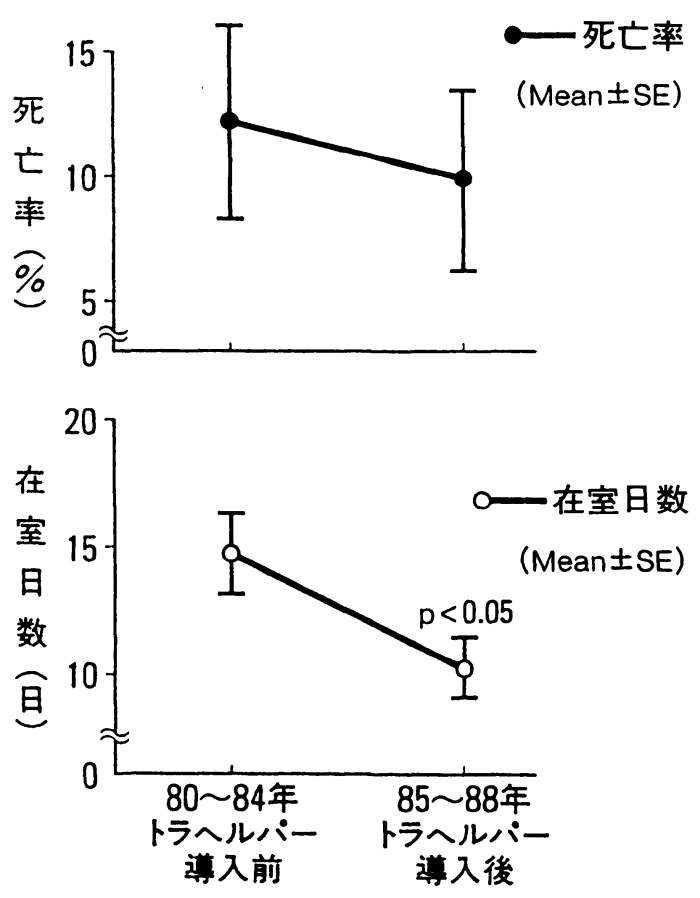

図 5 トラヘルパー導入による死亡率と在室日数の 变化

ると, 在室日数の大幅な短期化と, 若干の死亡 率の低下がみられた（図 5 )。

\section{$\mathrm{V}$ 考 察}

慢性呼吸不全に対する長期酸素療法の効果が 認められ ${ }^{3), 4)}, 1985$ 年より, 社会保険診療として 在宅酸素療法が実施されるようになった。また， 訪問看護体制の整備などにより，これらの患者 の予後は改善されつつあり, 人口の高齢化とも 関連して, 慢性呼吸不全患者は，近年次第に増 加する傾向にある．しかしながら，一旦増悪 すると，これらの患者は，換気予備能の減少， 進行した非可逆的病変などのため, 治療は非常 に困難で，急性増悪時の管理は，ますます重要 なものとなっている.
当 ICU では, 85 年と 86 年をピークに入室者数 の減少がみられた.この原因として ICU 入室の 防波堤となるべき病棟内科医の努力, 在宅酸素 療法の普及などが考えられるが，他の一因とし て，入退室を繰り返していた患者が慢性疾患の 終末像を迎えこの時期に多く死亡したために， 延べ入室者数の減少がみられたことが考えられ る.これらの患者の多くは，胸廓形成術後など の結核後遺症患者であり, 85年以降の結核後遺 症患者の減少からも裏づけされる。

疾患別患者数は，本邦での他機関の報告をみ ても，肺結核後遺症が高い割合を占める傾向に はあるが5) 7), 当 ICU では63.2\%と非常に高い 割合を占めた。これは，当院が1960年まで結核 専門病院として運営されていた歴史的背景が, 関与しているものと思われる. 結核後遺症の占 める割合は, 近年減少してきてはいるものの, まだしばらくは，重要な位置を占めるものと思 われる。

急性増悪と季節とは深い関連があるといわれ ており，奥津らは 9 例中 7 例が冬季に増悪した としており ${ }^{8)}$, また宮城は, 季節感の乏しい沖縄 においても冬季に急性増悪傾向がみられること を指摘している ${ }^{9)}$. 我々の結果でも, 冬に最も多 くみられたが，夏にもピークがあることが明ら かとなった。しかし，死亡率については，全く 逆の関係がみられた。この結果から，気候のき びしい季節には急性増悪をきたしやすく, ICU 入室者が多くなるが，春のような気候の良い季 節に，急性増悪をきたす症例は，予後が悪いと いうことが示唆される。

入室時 $70.3 \%$ 症例に意識障害を認めた。意 識障害を認めない群に比較し有意に死亡率が高 いことから，意識障害をきたすほどの重症とな る以前に ICU 管理下におくことが重要である 
と思われる. 入室時の $\mathrm{PaCO}_{2}$ は, $84.2 \pm 19.7 \mathrm{~mm}$ $\mathrm{Hg}$ ，最高 $180 \mathrm{~mm} \mathrm{Hg}$ と他機関の報告に比べ非常 に高い值を示している9).これは, 対象患者が ICU 管理を必要とする重症例であったためと 思われる. 生存群と死亡群の間に, 入室時 $\mathrm{PaCO}_{2}$ の值について有意差はみられず,むし ろ, 死亡群の方が低い傾向にあった。この結果 より, $\mathrm{PaCO}_{2}$ の值よりは, むしろ意識レベルの 方が重要であり, 入室時に意識障害の認められ る場合には，早期より人工呼吸を開始するなど の処置が必要であると思われる.

Doxapramの使用については, 賛否両論あ $3^{10), 11)}$. 今回の我々の調査では, Doxapram の 投与により挿管せずに管理し得た症例もみられ たが, 死亡率は投与群でむしろ高く, 全体でみ るとDoxapram が有効とはいい難い。これに は, 同薬の適応が多分に影響しているものと思 われる.すなわち, 呼吸中枢の $\mathrm{CO}_{2}$ 感受性低下 が同薬によって改善し,さらに呼吸筋疲労が進 行していない症例に限って適応があるものと考 えられる。しかし，適応を見分けるのは，とき に困難でもあり，いずれにしても長期の使用は 避けるべきであろう。

平均在室日数, $16.7 \pm 4.0$ 日は,この間の ICU 全体の平均在室日数 7.2 日の 2 倍以上であり, 他 の疾患に比べて, 長期入室となる傾向にあるこ とを示している。 また気切群では，これが, $33.8 \pm 5.7$ 日とさらに長期となる傾向がみられ たが,これらの患者では, 挿管抜管を繰り返し, 呼吸のウィーニングに難渋した結果, 気切を施 行するため在室期間が長くなるものと考えられ た.

当 ICUでは, 85 年よりミ二気管切開を導入し ている.これは, 水口らの考案した経皮的気管 穿刺針(トラヘルパー® ${ }^{12)}$ およびトラヘルパー®
刺入部をブジーの要領で段階的に拡張し，外 径 $6 \mathrm{~mm}$ 前後の小口径の気管カニューラを留置す るものである ${ }^{13), 14)}$.この方法の導入により,喀痰 排出困難症例に対する, 喀痰除去目的の気管切 開は, 極力回避することが可能となり, 気切症 例が激減するとともに, 在室期間の短期化がみ られている。

慢性呼吸不全の急性増悪時の呼吸管理につい ては, 従来より, 低流量の酸素で保存的に管理 することが原則とされてきたが15), 高度の呼吸 性アシドーシスを伴う場合，人工換気を行なわ ない時の死亡率は $60 \%$ にのるという報告もあ $\eta^{16)}$, 保存的療法に固執するのは得策ではない. さらに,人工呼吸を積極的に取り入れた管理に より好成績が得られたという報告も多い9),17). 我々の施設では，1）意識レベルが保たれてい ること，2）呼吸性アシドーシスが代謝性に代 償されていること，3）尿量減少がみられない こと，4）心不全の進行がないこと，5）頻呼 吸, 頻脈, 不整脈, 異常発汗のみられないこと, $6) \mathrm{PaO}_{2}$ を $50 \mathrm{~mm} \mathrm{Hg}$ 以上に保ち得ること，を条 件に調節酸素療法を行なった.ミニ気管切開(ト ラヘルパー®）導入前は，上記の条件に“喀痰 の自己排出が可能なこと”をあげていたが, 導 入後は, 必ずしも必要ではなくなったため, こ の項目を除外している.

我々の施設における挿管患者の救命率は $84.6 \%$ あ゙り，ミニ気管切開導入後は $86.4 \% に$ 達している。また，この方法を用いれば，早期 抜管も可能であり, 人工呼吸器による種々の合 併症も軽減しうる. 肺酸素化能に問題がある症 例や, 呼吸予備能が少ない症例では, 大容量の リザーバーバックをロ元に取りつけた正しい CPAP 装置 ${ }^{18)}$ を用いたり, CPAP レベルを間欠 的に上下させる変動 CPAP 換気法 ${ }^{19}$ を用いれ 
ばよい.これにより呼吸仕事量の軽減をはかる ことが可能であり, 呼吸筋疲労の進行を防ぐこ とができる，さらに，拘束性障害の強い肺や， 呼吸筋疲労の進んだ症例などには, pressure support ventilation ${ }^{20)}$ を用いることにより従来 よりも円滑にウィーニングを行なうことが可能 である.いずれにせよ，一旦人工呼吸を開始 すると呼吸器からのウィーニングが困難である ということから，保存的管理に固執するのは得 策ではないと考える。

なお，本論文の要旨は第 9 回日本臨床麻酔学 会総会（東京）において発表した。

\section{参考文献}

1) 第26回日本胸部疾患学会シンポジウム：呼吸不全の多臓 器障害. 日胸疾患会誌 $25: 149 \sim 202,1987$

2 ) 杼寉豊, 楠原範之, 石川高一ほか：慢性呼吸不全増悪例の 人工呼吸器による呼吸管理中の問題点-血圧の管理につ いて. 臨呼吸生理 $14: 107 \sim 111,1982$

3 ) Nocturnal Oxygen Therapy Trial Group : Continuous or nocturnal oxygen therapy in hypoxemic chronic obstructive lung disease. Ann Intern Med 93 : $391 \sim 398,1980$

4 ) Report of the Medical Reseach Council Working Party : Long term domiciliary oxygen therapy in chronic hypoxic cor pulmonale complicating chronic bronchitis and emphysema. Lancet $28: 681 \sim 685,1981$

5 ) 石原享介: 慢性呼吸不全の病態. 救急医学 11 : 1308 1313， 1987

6 ）中田紘一郎：慢性閉塞性肺疾患の急性増悪. 診断と治療 $73: 574 \sim 576,1985$
7 ）町田和子, 渡辺純一, 芳賀敏彦：慢性呼吸不全の呼吸管理 急性増悪時の治療及び持続酸素療法について。臨呼吸生 理 $14: 151 \sim 155,1982$

8 ）奥津芳人, 天羽敬祐, 井上一衛ほか： $\mathrm{CO}_{2}$ ナルコーシスの 治療経験- 9 症例の観察結果から. 麻酔 $26: 605 \sim 610$, 1976

9 ) 宮城征四郎：慢性閉塞性肺疾患 (COPD) の急性増悪に関 する臨床的研究. 京大胸部研紀要 $18: 27 \sim 41,1985$

10）大塚洋久: 呼吸刺激薬は必要か一必要. 呼と循 35 : 373 376, 1987

11）秋山也寸史, 川上義和：呼吸刺激薬は必要か一不要. 呼と 循 $35: 377 \sim 380,1987$

12）水口嘉治, 臼田正敏, 山田公雄ほか：経皮的気管穿刺法に よる肺合併症の救急処置. 救急医学 $21: 815 \sim 819,1979$

13）宮野英範, 中川隆, 清田豊秋ほか：気管切開の適応と方法 の見直し. ICU と CCU 13：119 126, 1989

14）宮野英範, 中川隆, 八田誠ほか：ミ二気管切開(トラヘル パー）による気道管理. 呼吸 $7: 207 〜 213,1988$

15) Daniele RP, Rogers RM : Oxygen and Nonventilatory Therapy of Respiratory Failure in COPD. Postgrad Med 54:145〜154, 1973

16) O'Donohue WJ, Baker JP, Bell GM : The Management of Acute Respiratory Failure in a Respiratory Intensive Care Unit. Chest $58: 603 \sim 610,1970$

17）岡崎薰：慢性呼吸不全の急性増悪. 臨床看護 9 ： 1089 1096, 1983

18）宮野英範, 間㴊則文, 早川潔ほか：CPAP 装置の各種デザ インによる呼吸仕事量の比較. ICUとCCU 12： $135 \sim 144,1988$

19）宮野英範, 安藤浩, 清田豊秋ほか：変動 CPAP 換気法. 臨床麻酔 $12: 725 \sim 730,1988$

20) Shelledy DC, Mikles SP : Newer models of mechanical ventilation part I : Pressure support. Respiratory Management, Jul/Aug : 14〜20, 1988

\author{
著者連絡先 西田 修 \\ $\overline{\mathbf{T}} 467$ 愛知県名古屋市瑞穂区瑞穂町字川澄 1 \\ 名古屋市立大学医学部麻酔・蘇生学教室
}




\title{
Management of Acute Exacerbation of Chronic Respiratory Failure in ICU
}

\author{
Osamu NISHIDA*, Hiroe TAKASU**, Syouji ITO**, \\ Kousuke KURIYAMA**, Makoto HATTA*, Kiyoshi ISHIKAWA* \\ * Department of Anesthesiology \& Resuscitatology, Nagoya City Univesity, Medical School \\ ** Division of Inensive Care, Nagoya Daininisseki Hospital
}

Patients with chronic respiratory failure who are suffering from advanced stages of irreversible pulmonary lesions, often have little respiratory reserve capacity. Therefore, in such cases, management is very difficult once the condition being exacerbated.

In this study, a retrospective investigation was made into the management of acute exacerbation of chronic respiratory failure in 185 patients admitted to our ICU for 9 yeares from Jan. 1, 1980 to Dec. 31,1988. These patients were characteristic in the following respects : they had been repeatedly admitted to our units; and many of them were suffering from pulmonary tuberculosis as in the past. With respect to relations to seasons, a marked tendency toward exacerbation was observed in winter and summer, while a high mortality was obtained in spring and fall. The mortality rate in patients with impaired consciousness on admission was high. Overall mortality rate was $10.8 \%$. Introduction of minitracheotomy resulted in a slight decrease in mortality and a marked decrease in duration of necessary treatment in our unit.

The Journal of Japan Society for Clinical Anesthesia Vol. 11 No. 2, 1991 